Article

\title{
Complexity Beyond Intersections: Race, Class, and Neighborhood Disadvantage among African American Muslims
}

\author{
Pamela Prickett \\ Department of Sociology, University of Amsterdam, 1001 NA Amsterdam, The Netherlands; E-Mail: prickett@uva.nl
}

Submitted: 10 February 2018 | Accepted: 4 April 2018 | Published: 22 June 2018

\begin{abstract}
This study uses the case of African American Muslims to examine the intersection of religious inequality with other forms of disadvantage. It draws on more than six years of ethnographic and historical research in an African American Muslim community in a poor neighborhood in Los Angeles, comparing the experiences of community members with existing research on first- and second-generation Muslim immigrants. It addresses the three most prominent axes of difference between African American and immigrant Muslims-race/ethnicity, class, and neighborhood disadvantage-to explicate the ways in which religion may compound existing inequalities, or in some cases create new forms of difference. It also shows how identifying as native-born Americans allows African American Muslims to claim religion as a cultural advantage in certain situations. Religion is complex not only when different forms of inequality intersect but when these intersections create a different way of understanding what religion means for people of faith.
\end{abstract}

\section{Keywords}

African Americans; American Islam; inequality; Muslim immigrants

\section{Issue}

This article is part of the issue "Complex Religion: Intersections of Religion and Inequality", edited by Melissa J. Wilde (University of Pennsylvania, USA).

(C) 2018 by the author; licensee Cogitatio (Lisbon, Portugal). This article is licensed under a Creative Commons Attribution 4.0 International License (CC BY).

\section{Introduction}

In the US, as in parts of Western Europe, Islam has acquired an undesirable public status as a foreign and "antiWestern" faith, with this discursive 'othering' becoming more amplified since September 11th (Byng, 2010; Charrad, 2011; Mahmood, 2005). According to polls, a majority of Americans seem to hold a more negative view of Islam than any other faith tradition in the US, and Muslims now are one of the most discriminated minority groups (Kishi, 2017; Pew Research Center, 2017a). Followers of the faith face an increasing threat of being victim to religious discrimination and hate-motivated violence (Considine, 2017). This is particularly true in cases where the outward expression of a Muslim identity makes believers more visible, as with veiling (Perry, 2014). Even Americans who do not identify with Islam but present themselves in some way that suggests they could be Muslim have become victims of anti-Muslim violence (Disha,
Cavendish, \& King, 2011). Collectively, this research suggests that the category 'Muslim' has become increasingly stigmatized in the US and represents, as such, a mechanism by which social inequality can be reproduced (Lamont, Beljean, \& Clair, 2014). However, the ways in which American Muslims experience stigma and inequality varies depending on how their religious identification intersects with other dimensions of social stratification.

Much recent research on the stigmatization and racialization of American Muslims focuses on the experiences of first- and second-generation immigrant Muslims (Abdullah, 2010; O'Brien, 2011; Selod, 2015). Putting this work in conversation with the small but rich literature on African American Islam enables us to get a fuller portrait of how religion intersects with other layers of difference and marginalization. Until the 1970s, blacks dominated the Muslim American population and "the Muslim presence in the US was synonymous with the modern AfricanAmerican experience" (Meer \& Modood, 2015, p. 532; 
see also Jackson, 2004). Though their proportion of the total Muslim population in the US has decreased as the number of foreign-born Muslims has increased, more than one in five American Muslims identifies as nativeborn black. Islam is, and for a long time has been, the second largest black religion (Jackson, 2005). Greater attention to the experiences of African American Muslims, who face stigmatization on multiple fronts, allows us to incorporate a longer history of marginalization into theoretical frameworks of inequality and Islam (Bilici, 2012)

In this article, I draw on more than six years of ethnographic and historical research in an African American Muslim community in a low-income neighborhood in Los Angeles to examine the interplay of religion, stigma, and social inequality. I situate my ethnographic findings in conversation with existing research on first- and secondgeneration Muslim immigrants, and in doing so identify three prominent axes of difference in the lived experiences between the populations-race/ethnicity, class, and neighborhood disadvantage. I then examine how African American Muslims in this study navigate their stigmatization and discrimination to explain the ways in which religion may compound existing inequalities, or in some cases create new forms of difference. At the same time, this study finds that religion offers a tool that believers use to combat inequality. I show how African American Muslims claim their native-born status as a cultural advantage over other Muslims, framing religious authority as one that can be heightened by nativist interpretations of Americanness. By changing their conceptions of religion to accommodate an intersection of felt differences, believers in this study demonstrate an ability to reconstruct religion in new ways. This article thus makes a distinct contribution to the study of 'complex religion' (Wilde, 2017; Wilde \& Glassman, 2016; Wilde \& Tevington, 2017) by highlighting that religious stigma intersecting with other forms of inequality transforms the very nature of religious experience.

\section{Literature Background}

Though relatively small in proportion to other religious populations in the US, Muslim Americans are exceptionally diverse. Of the estimated two to seven million Muslims in the US, the three largest subgroups are South Asian (35\%), Arab or Middle Eastern (25\%), and African American (20\%). ${ }^{1}$ The remaining proportion includes first- and second-generation immigrants from Africa and other parts of Asia, as well as some Latinos. According to Smith (2010, p. 29), "America today is home to the most heterogeneous Muslim community at any time or place in the history of the world".

Believers and scholars point to the diversity of American Islam as evidence of the potential for a colorblind ummah, a community of believers (Karim, 2008). Indeed, the believers I studied clung to the idea that Islam is a religion without race, telling me that there are no pictures or images of the Prophet Muhammad and therefore he cannot be identified as white, or black. As a male member explained to me, without an image of the Prophet to idolize there can be no one race that "holds it over another". In framing Islam as an alternative to Christianity, African American Muslims engage the faith in a way that enables them to feel they can overcome what Rouse (2004) has called the "emotional wounds" of centuries of social, cultural, and scientific negation.

However, three-fourths of all mosques in the US remain dominated by one ethnic group (Bagby, 2012a). In most cases, the dominant group is either South Asian, Arab, or African American. This suggests that despite adopting a doctrine that espouses racial equality, the Muslim American community is deeply segregated by race and ethnicity when coming together to worship (Leonard, 2003; Schmidt, 2004). Of the mosques that are evenly mixed, the most common combination is Arab and South Asian (Bagby, 2012a). African Americans tend to worship separately, often in segregated urban areas. Their mosques have fewer resources than immigrant-led ones (Bagby, 2012b), which may explain why the number of African American Muslim communities has declined over the past decade even as the number of mosques in the US continues to grow (Bagby, 2012a). Karim (2008) argues that in the American Muslim community, color lines run not between white and black but between African American and "immigrant", the term used both by scholars of American Islam and African American Muslim respondents to describe foreign-born Muslim Americans and their offspring.

"Immigrant" Muslims in general experience more social mobility than African American Muslims. Research shows that Arab and South Asian Muslims achieve higher occupational statuses and greater educational attainment than their African American religious sisters and brothers (Leonard, 2003; Wilde \& Tevington, 2017). They also indicate a preference for wealthier neighborhoods physically removed from inner city areas (Karim, 2008), using their higher incomes to align themselves with whites over blacks. Even African immigrants tend to fare better than their black counterparts, according to $A b$ dullah (2010). In his study of Muslims in Harlem, Abdullah $(2010$, p. 130) writes that many African Muslims are middle-class when they arrive in the US and as such are "already endowed with a higher socioeconomic status". This suggests that there is something more complex at play than race alone (Wilde, 2017).

African American Muslims not only earn less than immigrant Muslims, they also are more likely to live in areas where poverty rates are higher and the threat of being

\footnotetext{
${ }^{1}$ Some studies put African Americans at 30 to $40 \%$, South Asians between 25 to $30 \%$, and Arabs at 12 to $30 \%$ of the Muslim American population (Abdullah, 2010; Bilici, 2012; Leonard, 2003). However, the sources from which these scholars draw their figures are nearly 20 years old. More recent surveys (e.g., Pew Research Center, 2017b) suggest that the percentage of African American Muslims has decreased relative to other ethnic subpopulations, which is consistent with my ethnographic findings.
} 
victim to violent crime is greater (Karim, 2008; Wilson, 2009). From an abundant literature on urban poverty we know that living in such a neighborhood reduces nearly every measure for quality of life tested and opportunities for social mobility are greatly constrained (Sampson, 2012; Sharkey, 2013). Residents of poor neighborhoods suffer material hardship due to geographic and economic inequalities, as well as the stigmatization of being attached with an undesirable neighborhood (Sampson \& Raudenbush, 2004; Wacquant, 2008). African American Muslims must therefore navigate religious difference amidst trenchant racial and class inequalities, creating an opportunity to study the complex ways in which religious stigma intersects with other aspects of inequality. A central argument of this article is that race or neighborhood disadvantage alone are not as consequential as the intersection of multiple structural inequalities. The greater chance that African Muslims in less advantaged neighborhoods have to be embedded in an "ethnic safety net" that protects and possibly bolsters their socioeconomic status (Abdullah, 2010) indicates there is something qualitatively distinct about the way African American Muslims experience the intersection of race, class, and neighborhood inequalities that warrants further study.

\section{Setting and Methods}

"Masjid al-Quran" (MAQ) is one of the oldest Muslim communities in California. ${ }^{2}$ Composed of approximately 100 regularly attending members, with greater numbers on large Islamic holidays like Eid al-Fitr and Eid al-Adha, the MAQ community has deep roots in South Central. South Central is a dense pocket of land south and southwest of the downtown business district of Los Angeles. According to US census data, nearly all (98\%) residents are people of color. Latinos comprise a majority at roughly two-thirds, but the area continues to have a sizeable proportion of African Americans (Sides, 2012). South Central is important for its long history as the primary black space in the city (Hunt \& Ramón, 2010), but an area well known around the world as one of deep disadvantage. Residents face higher rates of unemployment and under-employment, greater dependence on government assistance, substandard housing options, overcrowded and low-performing schools, and a greater chance of being victim to violent crime when compared to other parts of the city and county (Martinez, 2016; Ong, Firestine, Pfeiffer, Poon, \& Tran, 2008). The majority of MAQ members live in greater South Los Angeles and many in the immediate neighborhood.

From May 2008 to August 2013, I participated in and observed a variety of religious and social activities at MAQ. I also worked on several planning committees and logged hundreds of hours volunteering at community events. For 13 months of the study, I lived four blocks from the mosque. During this time, I spent two to five nights per week at MAQ, making my visits nightly dur- ing Ramadan. As the study progressed, I spent increasing amounts of time with believers outside the mosque setting as well. I have continued to visit since 2013, making concerted effort to attend in the fasting month.

All data were analyzed using an abductive approach (Timmermans \& Tavory, 2012). Abductive analysis involves an iterative process of working with data in connection with diverse literatures (Tavory \& Timmermans, 2014). I was interested in understanding the everyday experiences of African American Muslims, with particular attention to those living in a disadvantaged urban context. When reading my data in light of the existing literature on American Islam, I was repeatedly struck with how different the problems believers expressed were from those reported by respondents in studies of South Asian and Arab Muslim Americans. For example, when I asked believers at MAQ to explain how their lives were different post-9/11, they said little had changed. They compared this to what they perceive as a greater sense of mistrust and discrimination by Americans towards "immigrant" Muslims, a conclusion with support in the literature on American Islam. Naber (2008) argues that Arab Americans went from "invisible citizens" to highly visible after the terrorist attacks in 2001, and Peek (2005) found that religion became a more salient source of identification among young second-generation Muslim Americans in the aftermath of the event. Yet, while September 11th was not a significant turning point for believers at MAQ, their transition from the Nation of Islam to Sunni Islam proved pivotal and stands as an important point of departure with other Muslim Americans.

\section{Complex Religion: Difference Compounding Inequality}

Based on the everyday lives of African American Muslims in South Central, I examine four areas in which the interaction between inequality and religion manifests into a distinct lived religious experience, starting with the history of the MAQ community and believers' collective past in the Nation of Islam. This history is important for understanding the differences believers feel within the ummah and their need to reframe Islam as a tool for combating racial inequality.

\subsection{A History of Difference and Disadvantage}

When the MAQ community formed in the 1950s, believers followed the teachings of Nation of Islam leader Elijah Muhammad. After Muhammad's death in 1975, the community transitioned from the race-specific ideologies of the Nation to more mainstream interpretations of Sunni Islam under the leadership of Muhammad's son, Imam W. D. Mohammed. Believers at MAQ see their roots in the Nation as evidence of a long tradition of Muslim worship in the US, drawing on this history for religious authority. However, their perspective differs from

\footnotetext{
${ }^{2}$ Names of specific places and people have been changed to protect participants' confidentiality.
} 
many dominant public and scholarly interpretations. In his presidential address to the Association for the Sociology of Religion, Williams (2010) argues that there was no 'American Islam' until post-1965 immigrants and their offspring brought Islam into greater "visibility, consciousness, and legitimacy" (p. 128). He describes earlier versions, like the Nation, as "locked within racially segregated African American communities" and therefore outside the American public sphere (Williams, 2010, p. 130). But this may be too strong, because white Americans did not ignore the Nation of Islam. Instead, they framed it as a protest movement intent on causing violence in America's inner cities, using this claim to justify a campaign of violence and repression of the movement's followers that garnered larger public support (Lincoln, 1961/1994; Sides, 2003). According to Lincoln, blacks had "open admiration" for the militant stance that Black Muslims took in their refusal to acquiesce to white oppression. The appeal of the Nation to residents living in impoverished urban areas caused fear among politicians and law enforcement agencies, who worried that it was just a matter of lighting a fuse (Lincoln, 1961/1994).

The ways in which earlier formations of African American Muslim community life have been framed to see the Nation as isolated and, by law enforcement, as a problem needing to be solved, creates difficulties for former followers even today. Believers think most Americans continue to hold an inaccurate portrait of the Nation in their minds, including other Muslims. The perception that their religious counterparts look down on them for coming to Islam through the Nation creates tensions between MAQ and other Muslims that compounds structural differences. So, even as believers try to position Islam as a colorblind religion in which no race can be superior, they complained that Arabs and Arab-Americans themselves violate this ideal by seeking to assert cultural dominance over other Muslims. For a while Sister Mariam attended a Saudi-funded mosque in another part of Los Angeles, but she stopped going after some of the sisters there pulled her aside to say she needed to have her ankles covered, showing me where her skirt hit about three inches above the ankles. Mariam lamented: "How you gonna tell me what to do?! In my country?"

Believers expressed frustration that immigrants assume African Americans know less about the religion as a result of their histories as "converts". They complained that immigrants want to correct their stances during prayer, which I observed once when a Moroccan sister told a line of sisters they should line up a certain way. All of the women in the prayer line were second-generation Muslims and, though younger than the woman giving directions, had grown up practicing Islam. Contributing to these layers of ethnic tension were believers' feelings that Arab Muslims look down at African American Muslims for their limited knowledge of the Arabic language (see also Karim, 2008, p. 41), a difference reinforced by the community's need to import Arabic speakers during Ramadan to lead Qur'anic recitation. Experiences led be- lievers to see themselves fighting misconceptions about their faith on two levels: the misconception held by many Americans that they are still members of the Nation of Islam and therefore hate whites, and the misconception that they know less about Islam than immigrant Muslims. As one sister said: "I'm tired of it....What do they think? We just came to the religion yesterday?" These findings are consistent with research in other African American Muslim communities, where respondents complain that immigrant Muslims act as though they have "a monopoly on understanding Islam, viewing African American Islam as a 'secondhand' version, despite the efforts of individuals like Imam W.D. to promote orthodox learning and scholarship in the community" (Ahmed, 2010, p. 209).

Though they feel stigmatized and marginalized as a result of their past in the Nation, believers at MAQ continue to frame the movement as one that focused on racial pride and self-empowerment. Under the Nation, MAQ established a number of brick and mortar businesses, including fish and soul food restaurants, grocery stores, and bakeries. Further raising their profile were the designated Fruit of Islam (FOI) "soldiers" who patrolled neighborhood streets to promote social order and monitor local activities. Said Imam Khalid of this time: "We lived in the neighborhood and for the most part we prevented violence, not start it". These memories evoke pride among members, even today. Believers take what they perceive as a source of difference and potential stigma within Islam - their community's origins in the Nation of Islam-and try to argue that they are better positioned to teach America about Islam given they are the original "indigenous" Muslims in America. When Imam W. D. Mohammed died in September 2008, the head imam at MAQ called a special meeting. Imam Khalid said he wanted to calm fears that African American Muslims no longer had a national voice and their concerns would be subsumed by immigrant Muslims. Khalid told the crowd of mournful believers, "Our leadership is indigenous Muslims and will remain indigenous". He said that if immigrant Muslims do not know this, "they can go out and learn themselves". Khalid encouraged believers to see themselves as leaders of Islam, following their own cultural traditions in dress and food: "I can eat me some cornbread, collard greens, and chicken and that's halal".

Khalid's words fit in a larger narrative that positions African American Muslims as model Muslim American citizens. Believers repeatedly stressed to me that as "indigenous" Muslims they knew how to separate faith from culture. One brother, Omar, explained that as nativeborn Americans, African Americans are better able to show how to be American and Muslim "in moderation". Omar explained this edict of balance applies to everything, even something seen as conventionally haram (forbidden), like alcohol. He referenced parts of the Qur'an that say there are some good things alcohol does for body, such as aiding in digestion, but that there are bad things about it and those bad things outweigh the good. So, he concluded, it is best not to drink alcohol. Omar's 
words convey a particular kind of logic for finding ways to be Muslim in US society without seeing it as a set of extreme rules. Believers and leaders at MAQ referenced this way of working out a balanced religious approach in light of dominant US culture as distinct from the ways they perceive immigrant Muslims as holding on to "their culture" once in the US. Believers at MAQ thus claim their native-born status as a cultural advantage.

Believers at MAQ also expressed frustration at African American Muslims who copied styles of dress and gender segregation they associated with Arab culture, such as the long tunic men wear in the Middle East that some African American Muslim men have started wearing. One brother mocked the masculinity of these men, saying they looked like they were wearing dresses. Another African American-led mosque in South Central was considered the "young people's mosque" and some believers at MAQ considered its stricter segregation between men and women during worship services and social events as evidence they were too influenced by immigrant Muslims. In that community, women were more likely to wear a style of hijab traditionally seen as Arab, compared with the West African-influenced head coverings worn at MAQ (see also Karim, 2008). The practice of polygamy also contributed to perceptions among MAQ members that some African Americans had been culturally corrupted by the influence of foreign interpretations of Islam. But in countering what they perceived as religious discrimination within the Muslim community with ethnocentric and gender discriminatory framings, believers reinforced ethnic differences that can contribute to the 'othering' of fellow Muslims.

\subsection{Race and Family Life}

In addition to facing discrimination as former members of the Nation of Islam, believers at MAQ experienced stigmatization and marginalization within their own families. Most African American Muslims are converts to Islam, having come to Islam as former Christians. Meanwhile, the vast majority of their family members remain Christian and, like three-quarters of African Americans overall, consider religion important (Pattillo-McCoy, 1998; Pew Research Center, 2014). Women and men members of MAQ have regular, ongoing social connections with Christian family members. In some cases, they live under the same roofs, forced to work out differences in the course of everyday life. As one Muslim respondent told me, African Americans must "represent Islam" to their families, and they feel a tremendous pressure to represent it well. Their families look at that one person and measure all of Islam. Members of the mosque act as family faith ambassadors, performing cultural work to explain and (sometimes) justify their Islamic beliefs and practices to people unfamiliar with the minority religion. This creates a pressure not found in existing research on Muslim Americans who are first- or second-generation immigrants born into Islam.
To understand how this plays out in everyday life, take the example of eating halal. Pork is present in many soul food dishes consumed by African Americans, but everyone I spoke to at MAQ avoided eating anything with pork or pork byproducts (ex., gelatin). As such, mosque members were limited in what they could eat at large family functions, finding their Christian family members resistant to accommodate recipe changes. One respondent, a middle-aged salesman, said that it took his aunt "maybe 10 or 15 years to really, to be conscious of it [putting pork in food]". And she was "the first one that really was conscientious about what she cooked". It was not until his aunt was willing to accept her nephew's dietary choices and to adjust her behavior that tolerance over food could occur.

African American Muslims have to navigate religious difference within their larger race community. Karim (2008, p. 85) explains:

The main difference between whites and African Americans is that the latter often identify with the Black Power images of Islam because of the Nation....Otherwise, they take in the same popular images that portray Islam as a threatening religion.

In spite of this, believers at MAQ openly expressed hope that their kin would someday find Islam too. This suggests that they saw their faith as a source of advantage and pride. Since they have to navigate religious difference and seek accommodation within their families, African American Muslims have few places besides the Muslim community to feel culturally safe as religious minorities. This can then amplify both the importance of a desire for equality in Islam as well as the sense of injustice at feeling discriminated against by other Muslims.

\subsection{In the Neighborhood}

Compounding differences believers feel with their family members and fellow immigrant Muslim believers are the differences the MAQ community experiences with neighbors. When the mosque opened, the neighborhood was more than $80 \%$ black, but in the time since, members have become an ethnic minority in the neighborhood. Latinos now outnumber blacks in the neighborhood nine to one. This changed urban landscape privileges other language, clothing, and food preferences, and such change creates a new religious ecology favoring Spanishspeaking Catholic and Pentecostal congregations. It is part of a process of urban change I have examined elsewhere (Prickett, 2014) and others have called the "Latin Americanization" of South Central (Sides, 2012). For the purposes of this article, the demographic change in the neighborhood is important because it heightens the difference that members of MAQ feel in the course of everyday life. It also has created new difficulties for the community by making it harder to recruit members, cutting into their ability to raise funds to grow. The organization 
has struggled to meet basic operating costs as a result of limited funds.

Put together with the patterns of interaction members experience with family and "immigrant" Muslims and what you have is a situation that could be overwhelming, making members of MAQ turn away from religion in search of constructing an identity that brings them closer with their families or US society. But they do not do this. I found that believers turned closer to Islam both to make sense of their changing social world and for strength to persevere. It also made them want to protect the mosque as a safe space for African American Muslims, sometimes at the expense of building bridges across ethnic divides. The head imam declared in a public lecture: "This is where we feel most comfortable-in communities populated by African Americans". His comments reinforced to believers a sense that racial segregation within the Muslim American community was logical and legitimated in the context of difference in which members must live. This has the unintended consequence of making MAQ inward-focused, and it comes to define the fourth and final section of my analyses in which I examine how these intersecting discriminations affect the religious experience for believers.

\subsection{Responding through Religion}

Examples from my research and those of other scholars studying African American Muslim communities, illustrate a more general point about religion and inequality. Many religious traditions teach tolerance and brotherly love, but they also exist within systems of racial categorization that place some categories squarely above others (Emerson, 2010). This is why we see Arab Americans often selecting "white" as their race on surveys and why South Asian Americans readily admit in interview studies to a preference for white neighborhoods and schools (Leonard, 2003; Karim, 2008). Both populations try to situate themselves within or next to a category that is privileged, seeking to align themselves by race or class, not religion. These categorical cleavages contribute to ethnic tensions that stand in stark contrast to the ideal of a colorblind ummah.

Believers at MAQ turn inwards to religion as they try to shut out the various, overlapping forms of discrimination they face. The way in which the religious experience changes as believers respond to a nexus of disadvantage from neighborhood, racial, and class differences is most visible during the annual fasting month of Ramadan. Because the mosque is well-known in the larger LA Muslim community as being located in a neighborhood with extreme poverty, MAQ became a place for Muslim charity during Ramadan, with donors sponsoring nightly dinners (iftar) and bringing used clothing and goods. Donors most often came from other, wealthier parts of the city or Southern California region, giving money or bringing food for iftar on behalf of another mosque or wealthy family. But there was little contact between the spon- sors and MAQ members, because sponsors rarely stayed to eat and if they did they often left soon after dinner, not making prayer at MAQ. What interactions I observed were tenser than those between members and African American visitors, with believers ignoring the immigrant guests or vice versa. Because of my researcher status, visitors to MAQ often felt freer to share with me their opinions about MAQ and its neighborhood. One woman, who visited each year to sponsor dinner, told me that her father had helped "build" the MAQ community but he left because the concerns of African American Muslims were different. Given that conversations between the woman and members of MAQ never went deeper than superficial conversation, I am not sure she would have been able to know what the concerns of the community were despite her annual tradition of trying to help. Nor did believers at MAQ make much effort to reach out to ask her concerns.

A similar pattern occurs when African American Muslims go into religious spaces dominated by foreign-born Muslims and their offspring. Rather than bridging social divides, these interactions seem to reinforce differences between the populations. In Karim's (2008) study of Muslim women in Chicago and Atlanta, an African American sister says: "Sometimes African Americans feel left out, or if they try to interact with people of other communities, they feel that they are not getting the type of response that they would like" (Karim, 2008, p. 55). Rouse (2004, p. 210), an African American researcher who studied Muslim women converts, recounts visiting the home of "a fabulously wealthy Pakistani family" and feeling too much of an outsider to stay, because of her race and what she perceived as the South Asian women's lack of interest in getting to know her.

African Americans historically and systematically have been cut out of the American dream, denied equal opportunities for education and work (Billingsley, 1999). Few older members of MAQ have acquired diplomas, with the head imam at MAQ reinforcing in khutbahs (sermons) that one did not need to acquire degrees to be educated. Believers also emphasized being self-taught. One sister said: "My father had a 3rd grade education but you never would have known meeting him". At the same time, education is a primary path to social mobility in contemporary US society. So, because many members lived in a neighborhood where educational resources are lacking and most residents do not have an opportunity to go to college, people in the MAQ community were less likely to achieve the socioeconomic advantages that their non-black religious brethren saw as of utmost concern for their children. When differences within a religious community align with structural inequalities in US society, it may reinforce and even perpetuate disadvantages. Such is what we see when members of MAQ feel they are looked down upon by South Asian and Arab American Muslims and fight back with disparaging remarks about other Muslims that deepen divides rather than bridge them (Prickett, 2015). Here too believers turn to religion 
as a tool to try to elevate their social standing by positioning their participation in the mosque as evidence of pious worth.

\section{Conclusion}

From a growing body of work on the stigmatization of Muslim Americans, we know that believers are finding creative ways to respond to suspicion and concern. O'Brien (2011) has shown how Muslim American youth engage in "stigma management rehearsals" to learn how to respond in interactions where they will be targeted as different for their religious identification. This work makes clear that non-dominant faith groups must work around a lack of religious accommodation. Resilience in the face of structural disadvantage and racial discrimination is one more way to "do religion" (Avishai, 2008). This complicates the religious experience because it shows how the pious can organize their lives in a way that incorporates inequality, rather than deny it.

While all Muslim Americans may experience stigma, African American Muslims have found their marginalization in the US compounded by race, class, and neighborhood inequalities. Members of MAQ face stigma on multiple fronts-on the streets of South Central, in their homes shared with non-Muslim family, and within the American ummah-and have thus had to work out an internal system of meaning-making to respond to their stigmatization. It seems reasonable to conclude that their efforts to frame African American Muslims as better suited to lead a 'balanced' portrayal of Islam to the American public is a form of stigma management. Knowing they experience multiple layers of disadvantage as ethnoracial minority residents of a low-income stigmatized neighborhood, they change what religion means and how it can work for them to account for the interaction of religion and inequality. Foreign-born Muslims may also feel different compared to their mostly white and Asian neighbors, and they also may identify with moderate interpretations of Islam. However, as previous work has demonstrated, immigrant Muslims do so in a context defined by greater socioeconomic advantage. They may be more able to circumvent certain stigmas by highlighting their job, education, and housing successes. By contrast, African American Muslims in this study have fewer opportunities to achieve mainstream markers of success. The multiple, intersecting forces of difference they face alter their understandings of-and experiences within-Islam, and religion becomes the framework for organizing a response to the complexities of social inequality.

\section{Acknowledgments}

The author wishes to thank Stefan Timmermans, Melissa Wilde, and two anonymous reviewers for helpful feedback.

\section{Conflict of Interests}

The author declares no conflict of interests.

\section{References}

Abdullah, Z. (2010). Black Mecca: The African Muslims of Harlem. New York, NY: Oxford University Press.

Ahmed, A. (2010). into America: The challenge of Islam. Washington, DC: Brookings Institution Press.

Avishai, O. (2008). "Doing religion" in a secular world: Women in conservative religions and the question of agency. Gender \& Society, 22(4), 409-433.

Bagby, I. (2012a). The American Mosque 2011: Basic characteristics of the American mosque (Report number 1). Washington, DC: Council on American Islamic Relations. Retrieved from www.cair.com/ images/pdf/The-American-Mosque-2011-part-1.pdf

Bagby, I. (2012b). The American Mosque 2011: Activities, administration, and vitality of the American mosque (Report number 2). Washington, DC: Council on American Islamic Relations. Retrieved from www.icna.org/wp-content/uploads/2012/06/TheAmerican-Mosque-Report-2.pdf

Bilici, M. (2012). Finding Mecca in America: How Islam is becoming an American religion. Chicago, IL: University of Chicago Press.

Billingsley, A. (1999). Mighty like a river: The Black church and social reform. New York, NY: Oxford University Press.

Byng, M. D. (2010). Symbolically Muslim: Media, hijab, and the West. Critical Sociology, 36(1), 109-129.

Charrad, M. M. (2011). Gender in the Middle East: Islam, state, agency. Annual Review of Sociology, 37, 417-437.

Considine, C. (2017). The racialization of Islam in the United States: Islamophobia, hate crimes, and "flying while brown". Religions, 8(9), 165.

Disha, I., Cavendish, J. C., \& King, R. D. (2011). Historical events and spaces of hate: Hate crimes against Arabs and Muslims in post-9/11 America. Social Problems, 58(1), 21-46.

Emerson, M. O. (2010). People of the dream: Multiracial congregations in the United States. Princeton, NJ: Princeton University Press.

Hunt, D., \& Ramón, A. C. (Eds.). (2010). Black Los Angeles: American dreams and racial realities. New York, NY: NYU Press.

Jackson, S. A. (2004). Preliminary reflections on Islam and Black religion. In Z. H. Bukhari, S. S. Nyang, M. Ahmad, \& J. Esposito (Eds.), Muslims' place in the American public square: Hopes, fears, and aspirations (pp. 201-221). Walnut Creek, CA: AltaMira Press.

Jackson, S. A. (2005). Islam and the Blackamerican: Looking toward the third resurrection. New York, NY: Oxford University Press. 
Karim, J. (2008). American Muslim women: Negotiating race, class, and gender within the Ummah. New York, NY: NYU Press.

Kishi, K. (2017). "Assaults against Muslims in U.S. surpass 2001 level". Pew Research Center. Retrieved from pewrsr.ch/2zMfEGA

Lamont, M., Beljean, S., \& Clair, M. (2014). What is missing? Cultural processes and causal pathways to inequality. Socio-Economic Review, 12(3), 573-608.

Leonard, K. (2003). Muslims in the United States: The state of research. New York, NY: Russell Sage Foundation.

Lincoln, C. E. (1994). The Black Muslims in America (3rd edition). Grand Rapids, MI: W. B. Eerdsmans. (Original work published 1961)

Mahmood, S. (2005). Politics of piety: The Islamic revival and the feminist subject. Princeton, NJ: Princeton University Press.

Martinez, C. (2016). The neighborhood has its own rules: Latinos and African Americans in South Los Angeles. New York, NY: NYU Press.

Meer, N., \& Modood, T. (2015). Religious pluralism in the United States and Britain: Its implications for Muslims and nationhood. Social Compass, 62(4), 526-540.

Naber, N. (2008). Introduction: Arab Americans and US racial formations. In A. Jamal \& N. Naber (Eds.), Race and Arab Americans before and after 9/11: From invisible citizens to visible subjects (pp. 1-45). Syracuse, NY: Syracuse University Press.

O’Brien, J. (2011). Spoiled group identities and backstage work: A theory of stigma management rehearsals. Social Psychology Quarterly, 74(3), 291-309.

Ong, P., Firestine, T., Pfeiffer, D., Poon, O., \& Tran, L. (2008). The state of South LA. Los Angeles, CA: UCLA School of Public Affairs.

Pattillo-McCoy, M. (1998). Church culture as a strategy of action in the black community. American Sociological Review, 63(6), 767-784.

Peek, L. (2005). Becoming Muslim: The development of a religious identity. Sociology of religion, 66(3), 215-242.

Perry, B. (2014). Gendered Islamophobia: Hate crime against Muslim women. Social Identities, 20(1), 74-89.

Pew Research Center. (2014). 2014 Religious Landscape Study (RLS-II). Washington, DC. Retrieved from assets. pewresearch.org/wp-content/uploads/sites/11/2015 /05/RLS-II-FINAL-TOPLINE-FOR-FIRST-RELEASE.pdf

Pew Research Center. (2017a). "Americans express increasingly warm feelings toward religious groups". Washington, DC.

Pew Research Center. (2017b). “U.S. Muslims concerned about their place in society, but continue to believe in the American dream". Washington, DC.

Prickett, P. J. (2014). Contextualizing from within: Perceptions of physical disorder in a South-Central L.A. African American mosque". City \& Community, 13(3), 214-232.
Prickett, P. J. (2015). Negotiating gendered religious space: The particularities of patriarchy in an African American mosque. Gender \& Society, 29(1), 51-72.

Rouse, C. (2004). Engaged surrender: African American women and Islam. Berkeley, CA: University of California Press.

Sampson, R. J. (2012). Great American city: Chicago and the enduring neighborhood effect. Chicago, IL: University of Chicago Press.

Sampson, R. J., \& Raudenbush, S. W. (2004). Seeing disorder: Neighborhood stigma and the social construction of "broken windows". Social psychology quarterly, 67(4), 319-342.

Schmidt, G. (2004). Islam in urban America: Sunni Muslims in Chicago. Philadelphia, PA: Temple University Press.

Selod, S. (2015). Citizenship denied: The racialization of Muslim American men and women post-9/11. Critical Sociology, 41(1), 77-95.

Sharkey, P. (2013). Stuck in place: Urban neighborhoods and the end of progress toward racial equality. Chicago, IL: University of Chicago Press.

Sides, J. (2003). L.A. city limits: African American Los Angeles from the Great Depression to the present. Berkeley, CA: University of California Press.

Sides, J. (2012). Post-ghetto: Reimagining South Los Angeles. Berkeley, CA: University of California Press, for the Huntington-USC Institute on California and the West.

Smith, J. I. (2010). Islam in America. New York, NY: Columbia University Press.

Tavory, I., \& Timmermans, S. (2014). Abductive analysis: Theorizing qualitative research. Chicago, IL: University of Chicago Press.

Timmermans, S., \& Tavory, I. (2012). "Theory construction in qualitative research: From grounded theory to abductive analysis". Sociological Theory, 30(3) 167-186.

Wacquant, L. (2008). Urban outcasts: A comparative sociology of advanced marginality. Cambridge: Polity.

Wilde, M. J. (2017). Complex religion: Interrogating assumptions of independence in the study of religion. Sociology of Religion. https://doi.org/10.1093/ socrel/srx047

Wilde, M., \& Glassman, L. (2016). How complex religion can improve our understanding of American politics. Annual Review of Sociology, 42(June), 407-425.

Wilde, M. J., \& Tevington, P. (2017). Complex religion: Toward a better understanding of the ways in which religion intersects with inequality. Emerging Trends in the Social and Behavioral Sciences: An Interdisciplinary, Searchable, and Linkable Resource. https://doi.org/10.1002/9781118900772.etrds0440

Williams, R. H. (2010). Creating an American Islam: Thoughts on religion, identity, and place. Sociology of Religion, 72(2), 127-153.

Wilson, W. J. (2009). More than just race: Being black and poor in the inner city. New York, NY: W.W. Norton \& Company. 


\section{About the Author}

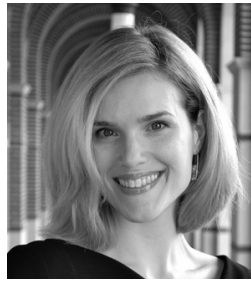

Pamela Prickett is an Assistant Professor in the Department of Sociology at the University of Amsterdam. She holds a Doctorate in Sociology from the University of California, Los Angeles, and master's degrees from the London School of Economics and University of Southern California. Her research interests include ethnography, urban sociology, sociology of religion, gender, death and dying. 